\title{
Metagenome of SARS-Cov2 patients in Shenzhen with travel to Wuhan shows a wide range of species - Lautropia, Cutibacterium, Haemophilus being most abundant - and Campylobacter explaining diarrhea
}

Sandeep Chakraborty

\section{Letter}

The metagenome of patients infected with SARS-Cov2 [1] has shown Prevotella to be a key player in immune response [2] in one Chinese study [3], just starting in another [4] and a host of other opportunistic pathogens in a study from San Diego county [5]. The metagenome can also be queried to find host response genes [5], as was done in monkey cells infected with SARS-Cov2 [6]

\section{Nanopore sequencing data from a familial cluster in Shenzhen}

The patients were tested for 4 bacterial species - Bordetella pertussis, Bordetella parapertussis, Chlamydophila pneumoniae, and Mycoplasma pneumoniae. The sequencing data (Accid:SRR10948474, Nanopore) from five patients in a family cluster from Shenzhen who presented with unexplained pneumonia after returning from Wuhan (Table 1) shows a wide range of bacterial species - Lautropia, Cutibacterium, Haemophilus being most abundant. The presence of Campylobacter explains diarrhea seen in the patient $[7,8]$. Also, their tests should have detected Mycoplasma, since it is there in the data.

\section{Significant bacterial load with some bacterial species predominating}

The bacterial reads are about $20 \%$ ( $95 \mathrm{~K}$ out of $500 \mathrm{~K}$ reads). The viral load is also significant here ( $70 \mathrm{~K}$ reads) [2]. They are in SI.familial/allsequences.fa. The number of bacterial species (with at least two reads) is 876 (SI.familial/list.allbacteria.txt). Thus, it is important to consider secondary infection, a possible reason why azithromycin (in addition to hydroxychloroquine) has given good initial results in a clinical trial [9].

\section{References}

1. Perlman S (2020). Another decade, another coronavirus.

2. Chakraborty S (2020). The 2019 Wuhan outbreak could be caused by the bacteria Prevotella, which is aided by the coronavirus, possibly to adhere to epithelial cells - prevotella is present in huge aemounts in patients from both China and Hong Kong. doi:10.31219/osf.io/usztn. URL osf .io/usztn.

3. Wu F, Zhao S, Yu B, Chen Y, Wang W, et al. (2020) Complete genome characterisation of a novel coronavirus associated with severe human respiratory disease in Wuhan. China bioRxiv 24.

4. Chen L, Liu W, Zhang Q, Xu K, Ye G, et al. (2020) RNA based mNGS approach identifies a novel human coronavirus from two individual pneumonia cases in 2019 Wuhan outbreak. Emerging Microbes \& Infections 9: 313-319.

5. Chakraborty S (2020). San Diego county Nanopore SARS-Cov2 sequencing data shows metagenomic Prevotella, Haemophilus parainfluenzae, a lot of unknown species and chimeric reads. doi: 10.31219/osf.io/cvbqf. URL osf.io/cvbqf. 
6. Taiaroa G, Rawlinson D, Featherstone L, Pitt M, Caly L, et al. (2020) Direct RNA sequencing and early evolution of SARS-Cov-2. bioRxiv .

7. Lindblom GB, Sjögren E, Hansson-Westerberg J, Kaijser B (1995) Campylobacter upsaliensis, C. sputorum sputorum and C. concisus as common causes of diarrhoea in Swedish children. Scandinavian journal of infectious diseases 27: 187-188.

8. Nelson JM, Smith KE, Vugia DJ, Rabatsky-Ehr T, Segler SD, et al. (2004) Prolonged diarrhea due to ciprofloxacin-resistant Campylobacter infection. The Journal of infectious diseases 190: 1150-1157.

9. Gautret P, Lagier JC, Parola P, Meddeb L, Mailhe M, et al. (2020) Hydroxychloroquine and azithromycin as a treatment of covid-19: results of an open-label non-randomized clinical trial. Inter-

Table 1: Bacterial secondary infections in a familial cluster of pneumonia indicating personto-person transmission [10] GN=Gram-negative, GP=GP, FAC-ANE=facultatively anaerobic (aerobic, but capable of switching to fermentation if oxygen is absent). Is there a link to anaerobic coinfection (like Prevotella, which is again present here)? Many more species, just listed top 30 here.

\begin{tabular}{|c|c|c|c|}
\hline NReads & Bacteria & Type & Diseases \\
\hline 16594 & Lautropia & GN FAC-ANE & oral cavities of HIV-infected children [11] \\
\hline 14330 & Cutibacterium & GP anaerobic & chronic blepharitis and endophthalmitis, \\
\hline 9618 & Escherichia & GN FAC-ANE & \\
\hline 5558 & Haemophilus & GN FAC-ANE & pneumonia, meningitis and bloodstream infection \\
\hline 4649 & Scytonema & cyanobacteria & \\
\hline 3798 & Hyphomicrobium & GN aerobic & \\
\hline 3289 & Capnocytophaga & GN FAC-ANE & usually occur with dog or cat bites \\
\hline 2440 & Burkholderia & GN aerobic & melioidosis [12] \\
\hline 2098 & Variovorax & GN aerobic & \\
\hline 1811 & Campylobacter & GN aerobic & diarrhoea $[7]$ \\
\hline 1781 & Pseudomonas & GN FAC-ANE & \\
\hline 1659 & Staphylococcus & FAC-ANE & Boils, impetigo, food poisoning, cellulitis, and toxic shock syndrome \\
\hline 1604 & Schaalia & GP aerobic & \\
\hline 1541 & Streptococci & GP aerobic & pharyngitis, pneumonia, sepsis, endocarditis, etc \\
\hline 1174 & Mycoplasma & Lack a cell wall & respiratory Mycoplasma pneumoniae [13] \\
\hline 1047 & Phyllobacterium & GN aerobic & \\
\hline 997 & Moraxella & GN aerobic & otitis media in infants and children [14] \\
\hline 940 & Flavobacterium & GN aerobic & fish pathogens \\
\hline 931 & Bacillus & GP FAC-ANE & Inhalation or respiratory anthrax \\
\hline 659 & Neisseria & GN aerobic & infection and persistence in the upper respiratory tract [15] \\
\hline 493 & Prevotella & GN anaerobic & aspiration pneumonia, lung abscess, pulmonary empyema, etc \\
\hline 463 & Fusobacterium & GN anaerobic & periodontal, tonsillitis, peritonsillar abscess, etc \\
\hline 358 & Veillonella & GN anaerobic & rare cases of meningitis, osteomyelitis, and periodontal disease \\
\hline 328 & Cupriavidus & GN aerobic & Infection in 87 yr Chinese man [16] \\
\hline 325 & Corynebacterium & GP aerobic & diphtheria toxin $[17]$ \\
\hline 318 & Sphingomonas & GN aerobic & \\
\hline 314 & Micrococcus & GP aerobic & anaphylactoid [18] \\
\hline 307 & Loriellopsis & cyanobacteria & \\
\hline 297 & Calothrix & cyanobacteria & \\
\hline 281 & Lysinibacillus & GP & Sepsis [19] \\
\hline 278 & Methylobacterium & GN aerobic & opportunistic pathogens in immunocompromised patients \\
\hline 277 & Treponema & $?$ & syphilis, bejel, and yaws \\
\hline
\end{tabular}


national Journal of Antimicrobial Agents : 105949.

10. Chan JFW, Yuan S, Kok KH, To KKW, Chu H, et al. (2020) A familial cluster of pneumonia associated with the 2019 novel coronavirus indicating person-to-person transmission: a study of a family cluster. The Lancet .

11. Rossmann SN, Wilson PH, Hicks J, Carter B, Cron SG, et al. (1998) Isolation of Lautropia mirabilis from oral cavities of human immunodeficiency virus-infected children. Journal of clinical microbiology 36: $1756-1760$.

12. Nieves W, Heang J, Asakrah S, Zu Bentrup KH, Roy CJ, et al. (2010) Immunospecific responses to bacterial elongation factor Tu during Burkholderia infection and immunization. PloS one 5.

13. Chu HW, Honour JM, Rawlinson CA, Harbeck RJ, Martin RJ (2003) Effects of respiratory Mycoplasma pneumoniae infection on allergen-induced bronchial hyperresponsiveness and lung inflammation in mice. Infection and immunity 71 : 1520-1526.

14. Goldstein EJ, Murphy TF, Parameswaran GI (2009) Moraxella catarrhalis, a human respiratory tract pathogen. Clinical Infectious Diseases 49: 124-131.

15. Weyand NJ (2017) Neisseria models of infection and persistence in the upper respiratory tract. Pathogens and disease 75 .

16. Zhang Z, Deng W, Wang S, Xu L, Yan L, et al. (2017) First case report of infection caused by Cupriavidus gilardii in a non-immunocompromised Chinese patient. IDCases 10: 127-129.

17. Murphy JR (1996) Corynebacterium diphtheriae. In: Medical Microbiology. 4th edition, University of Texas Medical Branch at Galveston.

18. Monodane T, Kawabata Y, Takada H (1997) Micrococcus luteus cells and cell walls induce anaphylactoid reactions accompanied by early death and serum cytokines in mice primed with muramyl dipeptide. FEMS Immunology \& Medical Microbiology 17: 49-55.

19. Wenzler E, Kamboj K, Balada-Llasat JM (2015) Severe sepsis secondary to persistent Lysinibacillus sphaericus, Lysinibacillus fusiformis and Paenibacillus amylolyticus bacteremia. International Journal of Infectious Diseases 35: 93-95. 